\title{
Corpus-assisted Analysis of Discursive Practices in Russian- language Genre of Press-release
}

\author{
Larisa Kochetova, and Elena Ilyinova \\ Volgograd State University, English Philology Chair, Russia
}

\begin{abstract}
Based on a comparative analysis of multiword keywords, this study provides insights into discursive practices used in Russian-language press releases. Although company press releases have been the object of intensive research, there is a lack of corpus-based studies in this field, especially with regard to the Russian-language texts. The present research investigates three corpora of various sizes that contain Russian companies' press releases retrieved from some companies' websites. With the SketchEngine tool [1], multiword keywords were identified and compared to provide insights into how words are employed to construe patterns of meaning in the genre under consideration. The results obtained show differences between the corpora with regard to the keywords identified, which suggests that lexical choices might indicate different values in discursive practices that are used to construe the company image and reach stakeholders and general public.
\end{abstract}

\section{Introduction}

Based on corpus linguistics methodology and framed within Discourse Theory, this study provides data from a linguistic analysis of corporate press releases published on websites of Russian companies that work in energy, food-producing and retailing sectors of economy. Being the genre of business communication, a corporate press release is characterized by a range of formal conventions, which reflect particular discursive and professional practices of the specific discourse community. Discursive practices in a professional context are understood as "the local, goal-driven actions that members of a professional community use to constrain and enable the unfolding discourse through recognized language" $[2 ; 19]$. As varying discursive and professional practices are represented by language features and items, acquiring a situated meaning in particular contexts, corpus linguistics in this case can help to identify values used by companies to construe and promote the image of themselves in the local community.

As any other genre, press releases are characterized by a set of communicative goals, which in turn determines the text structure and the use of lexicogrammatical as well as discourse resources $[3,4]$. The concept of genre also implies the existence of discourse community, which shares a set of common public goals, as well as discourse expertise [5]. Press release is a genre that is used as a precursor by journalists to create texts of their own [6-11]. M. Gundarin points out that the press release should "successfully launch an information bait to become a source of information for journalists" [7;12]. On the other hand, the press release is regarded as an independent genre, which is attributed to the news genres of media discourse [12], analytical journalistic genres [9]. In PR-communication, the company press release is classified as the main information genre containing up-to-date operational information about an event related to the subject of PR [8]. V. Tertychny views analytical press release as fulfilling two analytical and advertising purposes: "A journalist who is engaged into a task of writing a press release encounters the need to analyze relationship between meeting media audience expectations and promotional needs of firms, institutions, individual personalities" [9;242].

Due to the development of digital technologies, companies actively use press releases in the Internet. If the main function of a traditional press release is to inform media representatives, a press release produced by the company is intended for the general public. According to some linguists, press-releases are short written texts submitted to the media by companies, government agencies, political parties or non-profit institutions in order to provide the general public with news about those organizations [13]. Posted on the websites of organizations, press releases are available to anyone who has access to the Internet, they target an audience, which is heterogeneous, dispersed and difficult to estimate in terms of number but united by an interest in this organization. Thus, the addressee of press-release genre is being expended up to mass audience [14] that is comprised by various layers of discourse community and target groups $[6 ; 8]$, including investors and shareholders. However, the digital trend causes some heat discussions on the point of language

\footnotetext{
*Corresponding author: ilynov@volsu.ru
} 
clarity and style. In the opinion of 'old-school journalists' the above stated new information delivery environment results in quick plunging in the manner of speech. In particular, newly coined "digital amateurs" are gaining public respect by the quick dissemination of news and information, but their language, full of exciting, jargon and buzzwords with which they try to describe companies in their press releases, can do a brand or company more harm than good. Professionals in the sphere of PR-writing and editing point out that the news release should be "informative, that it should contain less corporate jargon and more accurate and relevant news" $[15 ; 110]$. This is due to the fact that, on the one hand, the text of the press release should be logical, concise, accurate in conveying the facts, and claim an objective description. And on the other - it should not be emotionally colored, there should not be a direct appeal to the audience or a direct appeal of the author, which is typical of a journalistic press release.

As a genre, press release is to perform both informative and promotional functions. Generally, corporate press releases are thought to be not only informative, but pursue another goal, that is the social approval of their activities. According to Sagiv and Schwartz [16], companies need to evolve in harmony with the societal collectivity in which they are nested, in order to secure a workforce as well as all the necessary materials and financial resources. In other words, companies should make their values compatible with those of the society in which they are nested, and, most importantly, they are to convey them to the general public. Press releases seem to be suitable tools in communication channel. They come in various types that are distinguished by a thematic criterion:

a general news press release, that introduces some newsworthy topic with the purpose to cover it in online and off-line media;

an event-based press release, which is formed by the news about the event that is characterized by a certain time point and are often socially marked and designated for a mass audience;

a launch press release, that relates to presenting a new product, new company, new website to the public;

a product-classifying press release that contains product specifications;

a report press release that gives account of the commercial activities of the company and addresses potential investors and shareholders;

a press release that gives formal notices, criticizes, or represents acts of denunciation.

The previous research states that the language of press releases includes the use of superlatives, evaluative adjectives outside of quotes, direct reader address and imperatives [17-18]. With this in mind, one would expect the keywords identified in the corpora based on collections of press releases to contain a range of such items. Given that companies are interested in projecting a positive socially approved image, one can reasonably hypothesize that companies that represent different sectors of economy would be likely to recur to identical discursive practices, detectable through their press releases.

This study aims to approach this area of research by looking into the differences between keywords detected in three corpora of Russian-language corporate press releases available on the websites of companies that work in different sectors of economy in Russia.

Therefore, our research is held with the aim to identify similarities and differences between the range of key words in the corpus of corporate press releases written and published in face of Russian companies. The study will try to answer the following research questions: (i) What keywords do organizations use in conveying a wide range of news over the same time period? (ii) What do the keywords disclose about the possible salient patterns of meaning? Given the fact that most of the Russian language texts are addressed to culturally identical readerships (that is, localization within businesses and communities of RF and their business partners), the keywords retrieved may demonstrate certain variations related to the company's image that is being construed by tools of press release discourse. Due to the multi keyword function available in the SketchEngine tool [19], an in-depth contextual analysis of keywords revealed variations in the use of collocations with general meaning and specific meaning words, and colligation. This type of approach will help shed light on the informative foci chosen in communicating news by companies from various business segments.

\section{Methodology and corpus}

\section{A. Research design}

Having the goal to compare discursive practices used in the professional genre of corporate press releases, the research was designed to investigate semantic categories expressed by key words in the three corpora and reveal specific values used by companies to promote their image. Firstly, by using the corpus linguistics method the keywords in the three corpora were identified, i. e. the unusually frequent lexical items defined against a reference corpus, which can enable the detection of recurrent patterns of meaning, that would otherwise be difficult to access and recognize, especially in a horizontal reading of texts in a corpus [20-21]. These were identified by the SketchEngine software tool [1] that builds and then compares the frequency lists of a reference corpus and a corpus whose keywords one is interested to find out. The choice of the reference corpus has a direct impact on the results obtained, because different lexical items can be identified as key in the corpus under investigation, thus making the selection of the reference corpus a very important issue. Due to the purpose of the study "to conduct a comparative analysis of the three corpora", a reference corpus that includes texts functioning in the same medium was collected. Therefore, lists of the keywords for the three corpora were compiled and compared against the featured Russian-language Corpus Rutenten 2011. Lexical items 
related to the descriptions of the companies' activities were selected manually and put into a table with indicated Keyness Score $(K)$. At the next stage, the key lexical items from the three corpora were categorized along the following categories: proper names, technical terms, general lexical items, evaluative lexemes. The function of keywords in SketchEngine software tool allows extracting not only single keywords but also multi-word keywords, which considerably facilitates the identification of values.

The amount of data obtained from the corpus was used for an in-depth contextual analysis of the multiword keywords with the aim to identify the lexis used to construe values used by companies to project a positive image of themselves to the discourse community. Given the fact that companies belong to distinct industries, it is crucial to understand what types of values they appeal to, and whether, indeed, there is a large discrepancy in the value content between companies that operate in different sectors in Russia, or how this difference can be conceptualized. Our suggestion is that due to the rather ambiguous and subjective nature of value perception, different sectors might reveal nuances and peculiarities in the ways the image is being construed.

To answer the first research question, the keywords from each of the lists were categorized as their formal representation in the texts, their semantics was revealed. The following analysis of the implied values was based on differences in the keywords that are likely to point to patterns of meaning, especially if their collocations are regarded. As the SketchEngine tool allows for keyword collocations extraction, they were explored to identify patterns of meaning they convey.

\section{B. Corpus design}

The corpus includes texts retrieved from Russianlanguage official websites of market leaders in energy, food-producing and retailing industries. The texts were extracted from the press-release section of the site between January 2017 and March 2018. Among the companies under investigation are leading Russian state-owned and private energy companies that at a varying extent operate on a global scale (Lukoil, Rosneft', Gaspromheft). They have a great impact on the Russian economy as they are the major tax-payers to the budget. Besides there are private companies that produce food (Miratorg, Rusagro, Cherkizovo) and play the key role in the development of the agricultural sector, retailing companies (Lenta, X5 Retail Group, Magnit) that have outlets in most parts of the country.

The press releases that were published on the companies' websites from 2017 to 2018 were to cover the broadest possible range of themes, such as company management, corporate responsibility, technological innovation, or financial results, social and communal usefulness or environmental care.

The average number of words per text varies in each corpus: the energy companies corpus (EC) and the foodproducing companies corpus (FC) are quite similar in this sense, with 266 and 298 words respectively. The retailing companies corpus (RC) differs slightly, registering an average of 202 words per text. However, within each corpus an average number of words per text varies significantly: some companies such as Lukoil or Rusagro publish shorter texts as compared to the other companies in the sector. The composition of the corpus under investigation is presented in Table 1.

Table 1. The composition of the corpus.

\begin{tabular}{|c|c|c|c|}
\hline Corpus & $\begin{array}{c}\text { Number } \\
\text { of } \\
\text { Tokens } \\
\text { for } \\
\text { Corpus } \\
\end{array}$ & $\begin{array}{l}\text { Number } \\
\text { of Texts }\end{array}$ & $\begin{array}{c}\text { Average } \\
\text { Number } \\
\text { of } \\
\text { Tokens } \\
\text { per Text }\end{array}$ \\
\hline $\begin{array}{l}\text { Energy } \\
\text { companies } \\
\text { (EC) }\end{array}$ & 92. 397 & 347 & 266.27 \\
\hline Gazpromneft & 1.9471 & 58 & 335.7 \\
\hline Lukoil & 34.756 & 197 & 176.42 \\
\hline Rosneft & 38.170 & 92 & 414.89 \\
\hline $\begin{array}{l}\text { Food- } \\
\text { producing } \\
\text { companies } \\
\text { (FC) }\end{array}$ & 83. 632 & 280 & 298.68 \\
\hline Cherkizovo & 33.681 & 100 & 367.57 \\
\hline Miratorg & 41.964 & 160 & 280.66 \\
\hline Rusagro & 1.752 & 20 & 19.69 \\
\hline $\begin{array}{l}\text { Retailing } \\
\text { companies } \\
\text { (RC) }\end{array}$ & 21.468 & 106 & 202.52 \\
\hline Magnit & 16.395 & 85 & 192.88 \\
\hline $\begin{array}{l}\text { X5 Retail } \\
\text { Group }\end{array}$ & 2.009 & 8 & 251.12 \\
\hline Lenta & 3064 & 13 & 235.69 \\
\hline
\end{tabular}

The corpora of energy and food-producing companies are nearly identical in size whereas the corpus comprising texts from retailing companies is much smaller, which is due to the number of materials available on the websites.

\section{Results}

Multi-word keywords were extracted from the compared corpora, in numbers restricted to two hundred words, which is set as a cut-off point. As the number of keywords is usually very high, it seems sensible to facilitate the data examination, as the lexical items, which are rarely used in the corpora, are thus eliminated 
and a greater focus can be placed on more frequently used items.

From the point of view of lexical differences, the press releases of energy and food-producing companies seem to be the most distinct from standard Internet texts, as can be seen from the number of keywords, while the texts from retailing companies are the least different in this sense.

\section{A. Key words in press-releases of energy companies (EC)}

As the data show (Table 2), keywords in the EC corpus are represented by proper names of the companies' owners or Chief Executives, as well as the top position titles, which are characterised by the highest key score. Other semantic classes include lexemes that describe the companies' production and financial activity that is positively evaluated and technicalities. These keywords indicate that texts in the corpus are report press releases that give account of the production and commercial activities of the company and address potential investors and shareholders. Other multiword keywords are financial terms ('cash flow' - 311.78; 'sales volume' 152.51; 'internal auditing' - 143.59), technical terms ('carbohydrate pumping' - 459.60), lexis conveying the idea of growth and development ('production output' 437.70, 'production growth' - 419.45, 'dynamics of production' - 116.86). They indicate that report press releases generally give account of the commercial activities of the company and are addressed to potential investors and shareholders. Remarkably, lexemes related to the environmental issues that are characteristic of Western-based energy companies are not present in our data. It signals that the companies are mainly oriented towards investors but not community members. Given that the keyword collocation St Petersburgh International Economic Forum (200.97) has 29 occurrences, economic forum has 96.85 (42 occurrences in the corpus), we can conclude that eventbased press-release texts dominate in the corpus studied.

Table 2. List of multi-word key words extracted from the subcorpus of energy companies press releases ranged according to co-occurrence count.

\begin{tabular}{|c|c|c|c|}
\hline 幽 & 㤩 & $\underbrace{0}_{0}$ & 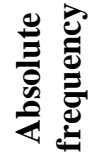 \\
\hline 1 & PAO President & 722.89 & 81 \\
\hline 2 & PAO Director & 675.62 & 76 \\
\hline 3 & $\begin{array}{ll}\text { Chief } & \text { Executive } \\
\text { Director } & \\
\end{array}$ & 508.99 & 57 \\
\hline 4 & Igor' Sechin & 482.26 & 54 \\
\hline 5 & $\begin{array}{l}\text { carbohydrate } \\
\text { pumping }\end{array}$ & 459.60 & 66 \\
\hline 6 & production output & 437.70 & 49 \\
\hline
\end{tabular}

\begin{tabular}{|c|c|c|c|}
\hline 7 & production growth & 419.45 & 47 \\
\hline 8 & mln tons & 446.61 & 50 \\
\hline 9 & production growth & 437.70 & 49 \\
\hline 10 & cash flow & 311.78 & 39 \\
\hline 11 & Board of Directors & 277.28 & 31 \\
\hline 12 & PAO shareholders & 267.83 & 30 \\
\hline 13 & $\begin{array}{l}\text { St Petersburgh } \\
\text { International } \\
\text { Economic Forum }\end{array}$ & 200.97 & 29 \\
\hline 14 & the newest project & 197.07 & 22 \\
\hline 15 & the highest level & 188.16 & 21 \\
\hline 16 & sales volume & 152.51 & 17 \\
\hline 17 & $\begin{array}{l}\text { modernization } \\
\text { programme }\end{array}$ & 197.07 & 22 \\
\hline 18 & cooperation strategy & 170.33 & 19 \\
\hline 19 & internal auditing & 143.59 & 16 \\
\hline 20 & Vagit Alekperov & 143.59 & 16 \\
\hline 21 & $\begin{array}{l}\text { Deputy of General } \\
\text { Director }\end{array}$ & 134.68 & 15 \\
\hline 22 & production volume & 134.68 & 15 \\
\hline 23 & the year of ecology & 125.77 & 14 \\
\hline 24 & $\begin{array}{l}\text { localization } \\
\text { production }\end{array}$ & 125.77 & 14 \\
\hline 25 & $\begin{array}{l}\text { cooperation } \\
\text { development }\end{array}$ & 125.77 & 14 \\
\hline 26 & $\begin{array}{l}\text { dynamics of } \\
\text { production }\end{array}$ & 116.86 & 13 \\
\hline 27 & strategic partners & 116.86 & 13 \\
\hline 28 & PAO cooperation & 116.86 & 13 \\
\hline 29 & project development & 107.95 & 12 \\
\hline 30 & economic forum & 96.85 & 42 \\
\hline
\end{tabular}

\section{B. Key words in press-releases of food-producing companies (FC)}

As the data show (Table 3), keywords in the FC corpus are represented by lexemes that underpin the traditional advertising values of quality, safety and low price. Remarkably, proper names of the companies' owners and Chief Executives, as well as highest position titles are absent from the list. The texts target investors as they construe the image of the market leader and provide information about the company's performance that is positively evaluated, which is proved by the top presence of words that introduce leading sectors of food production ('meat-producing' - 953.11; 'beef producer' - 267.25), statistics supported with quantitative units ('the largest producer' - 898.37; 'thousands of' 770.18 , etc.). 
Table 3. List of multi-word key words extracted from the subcorpus of retailing companies press releases ranged according to co-occurrence count.

\begin{tabular}{|c|c|c|c|}
\hline 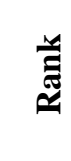 & 恶 & 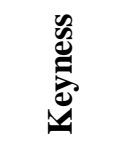 & 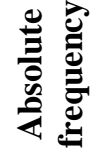 \\
\hline 1 & $\begin{array}{l}\text { meat-producing } \\
\text { company }\end{array}$ & 953.11 & 98 \\
\hline 2 & the largest producer & 898.37 & 91 \\
\hline 3 & thousand of & 770.18 & 78 \\
\hline 4 & millions of & 365.87 & 37 \\
\hline 5 & $\begin{array}{l}\text { the largest beef } \\
\text { producer }\end{array}$ & 267.25 & 27 \\
\hline 6 & food safety & 178.50 & 18 \\
\hline 7 & high quality meat & 178.50 & 18 \\
\hline 8 & thrifty production & 178.50 & 18 \\
\hline 9 & sales in the segment & 158.78 & 16 \\
\hline 10 & Russian producer & 148.92 & 15 \\
\hline 11 & mln eggs & 139.06 & 14 \\
\hline 12 & $\begin{array}{l}\text { the largest meat } \\
\text { producer }\end{array}$ & 139.06 & 14 \\
\hline 13 & production growth & 139.06 & 14 \\
\hline 14 & increase in livestock & 139.06 & 14 \\
\hline 15 & vertical integration & 129.20 & 13 \\
\hline 16 & decent salary & 119.33 & 12 \\
\hline 17 & $\begin{array}{l}\text { leader in meat } \\
\text { industry }\end{array}$ & 119.33 & 12 \\
\hline 18 & profit in the segment & 119.33 & 12 \\
\hline 19 & integrated production & 119.33 & 12 \\
\hline 20 & the largest employer & 119.33 & 12 \\
\hline 21 & wider assortment & 119.33 & 12 \\
\hline 22 & extension of project & 114.86 & 12 \\
\hline 23 & long-term strategy & 111.38 & 15 \\
\hline
\end{tabular}

However, the texts are more community-oriented as they construe the image of the companies that are socially significant as they provide job places (employer, long-term strategy).

\section{Key words in press-releases of retailing companies (RC)}

As the data shows (Table 4), keywords in the RC corpus are represented by a smaller number of keywords. Lexical choices suggest that retailing companies publish texts that are launch press-releases giving information about new shops that are opened in different locations and address potential investors and shareholders as well as community members.
Discursive practices employed by these companies are specific in the sense that they accentuate orientation to local producers and position themselves as food producers as texts stress ('own production' - 180.96; 'local producer' - 376.56; 'production of regional producers' - 563.96). The companies stress that they meet customers' needs as they focus on such values as choice, low prices and quality. The keyword 'family budget' (226.27) has 18 occurrences in the corpus; 'wider choice' has 829.16 (22 occurrences in the corpus); 'high quality goods' 165.11 occurs 9 times in the corpus.

Table 4. List of multi-word key words extracted from the subcorpus of retailing companies press releases ranged according to co-occurrence count.

\begin{tabular}{|c|l|c|c|}
\hline \multicolumn{1}{|c|}{} & \multicolumn{1}{|c|}{} & & \\
\hline 1 & a retailing net & 953.54 & 23 \\
\hline 2 & $\begin{array}{l}\text { own production of } \\
\text { the company }\end{array}$ & 849.80 & 23 \\
\hline 3 & a wider choice & 829.16 & 22 \\
\hline 4 & newest shop & 716.23 & 19 \\
\hline 5 & $\begin{array}{l}\text { produce of regional } \\
\text { producers }\end{array}$ & 563.96 & 15 \\
\hline 6 & local producer & 542.05 & 16 \\
\hline 7 & a thousand positions & 496.72 & 14 \\
\hline 8 & spacious parking & 409.35 & 11 \\
\hline 9 & $\begin{array}{l}\text { customers } \\
\text { convenience }\end{array}$ & 394.70 & 12 \\
\hline 10 & the newest format & 377.49 & 10 \\
\hline 11 & local producer & 376.56 & 20 \\
\hline 12 & reduction in prices & 374.44 & 10 \\
\hline 13 & launching a shop & 270.58 & 11 \\
\hline 14 & meeting needs & 264.50 & 7 \\
\hline 15 & family budget & 226.27 & 18 \\
\hline 16 & own production & 180.96 & 25 \\
\hline 17 & high quality goods & 165.11 & 9 \\
\hline
\end{tabular}

\section{Conclusion}

Based on the quantitative data on keyword variation data between press releases from energy, foodproducing and retailing companies in Russia, the study reveals possible differences in discursive practices. Given there is a need to provide more evidence on business communication in Russia, we hope that this study remedies the scarceness of available data and advances the field of study. The analysis of the lexical differences between the three corpora has revealed significant variation in business discursive practices between the company press releases from different sectors of economy.

As the analysis shows the list of keywords extracted from the three corpora does not have the company 
names (e.g. Lukoil, Rosneft', Magnit, Miratorg, etc.). Instead, press releases use hypernyms ('kompaniya company' or 'proizvoditel' - producer') modified by evaluative (often in the superlative forms) or descriptive attributes (mainly 'regionalnyi - local', 'rossiyskyi Russian'), it serves the general purpose of promotion, and may be symptomatic of a particular discursive practice.

Adjectives, most of which have an evaluative meaning, are presented in all the three word lists. The EC keyword list in Table 2 includes the lexemes 'highest' and 'newest', the FC keyword list in Table 3 has 'largest', 'high' and 'thrifty', 'decent', 'wider', 'long-term', 'Russian'; and the RC keyword list in Table 4 has 'wider', 'newest', 'local', 'own', 'high'. These are not only adjectives, but certain generalmeaning key nouns also have been used to express evaluation. This is the case of 'dynamics', 'growth', 'development' in the EC, 'safety', 'leader', 'quality' in $\mathrm{FC}$, and 'quality', 'convenience', 'reduction' in the RC. The EC and FC keyword lists are markedly different from the RC one in that they focus on growth that seems necessary to strengthen the positive image of the companies in question.

The results of the keyword analysis point to texts from energy companies as being the most specific in the ways the image is presented, as they highlight the company management and technicalities of the energy industry, while in the press releases of food-producing companies the focus is placed on social significance, production and sales. Retailing companies seem to be customer oriented and use discursive practices that are close to advertising techniques, as they stress low prices, convenience and construe their image as important local producers.

The study is part of the project 'Discursive practices in Russian-language genres', Volgograd State University.

\section{References}

1. A. Kilgarriff, P. Rychly, P. Smrz, D. Tugwell, The Sketch Engine. URL: https://www.researchgate.net/publication/26722398 1_The_Sketch_Engine (date of access: 06.04.18).

2. M. Handford, Professional communication and corpus linguistics, Corpus Applications in Applied Linguistics. (London and New York, Continuum International Publishing Group, 13-29, 2012).
3. V. Bhatia, Analysing Genre: Language Use in Professional Settings (Harlow, Longman, 1993).

4. V. Bhatia, Worlds of Written Discourse (London, Continuum, 2004).

5. J.M. Swales, Genre Analysis. English in Academic and Research Settings (Cambridge, Cambridge University Press, 1990).

6. S.V. Volodina, Vestnik Moskovskogo universiteta, Series 10, Journalism, 5, 28-33 (2007) (in Russian).

7. M. Gundarin, Press-release (Rostov-on-Don, 2013)

8. A.D. Krivonosov, Genres of PR-tests (Saint Petersburg, Laboratory of press (Faculty of Journalism, St Petersburg University), 2001) A.A. Tertichnyi, Genres of periodical press (Moscow, Aspect Press, 2011)

9. S.A. Wilcox, Critical Studies in Media Communication 20(3), 225-247 (2003).

10. L.V. Selezneva, Scientific researches and projects. Modern communicative science 4 (11), 47-54 (2014)

11. M.V. Busigina, Genre, functional-and-semantic characteristics of press releases in modern media discourse: theses (Volgograd, 2010) (in Russian).

12. I.S. Jacobs, C.P. Bean, Magnetism III, New York: Academic, 271-350 (1963)

13. M.R. Zheltukhina, Yu.A. Makarova, On Genre "popularizing article", Linguistics of Speech. Media stylistics (Moscow, Flinta-Nauka, 302-319, 2012)

14. D. Breckenridge, PR 2.0: New Media, New Tools, New Audiences (Moscow, 2010)

15. L. Sagiv, S.H. Schwartz, European Journal of International Management, 1(3) 176-190 (2007).

16. M.V. Mukhina, Science Journal of Volgograd State University. Series 2, Linguistics 1(13), 33-37 (2011)

17. E.S. Ryzhenko Science Journal of Volgograd State University. Series 2, Linguistics 1(17), 150-155 (2013)

18. SketchEngine (Version 3.4.3) [Computer Software]. URL: https://www.sketchengine.eu/ (date of access: 11.03.18).

19. M. Scot, System 25(2), 233-245 (1997).

20. M. Stubbs, 'Three concepts of keywords.' Keyness in Texts. (Amsterdam, John Benjamins, 21-42, 2010). 